\title{
酸分解一中和滴定法による粒状洗刘中の炭酸塩の定量
}

\author{
長谷川 章* · 塚 博 司* - 辻和 郎** \\ $*$ 花王石嗝株式会社杤木研究所 (杤木県芳賀郡市員町赤羽 2606) \\ ** 花王石䖒株式会社和歌山研究所（和歌山県和歌山市湊 1334）
}

\section{Determination of Carbonate in Detergent by the Acid-decomposition/ Neutralization Titration Method}

\author{
Akira Hasegawa*, Hiroshi Ohtsuka*, and Kazuro Tsuji** \\ * Tochigi Research Laboratories, Kao Corporation (2606, Akabane, Ichikai-machi, \\ Haga-gun, Tochigi) \\ ** Wakayama Research Laboratories, Kao Corporation (1334, Minato, Wakayama-shi, \\ Wakayama)
}

\begin{abstract}
A simple and rapid method for the determination of carbonate was developed. A carbonate sample was decomposed in a hydrochloric acid solution and the evolved carbon dioxide was absorbed in a barium hydroxide solution. The absorption was carried out with apparatus consisting of two gas washing bottles with a circulating air pump (Fig.-1). The air pump was operated for $5 \mathrm{~min}$ to fix carbon dioxide completely in the barium hydroxide solution to form $\mathrm{BaCO}_{3}$. Finally, the excess barium hydroxide was titrated with a standard solution of $1 \mathrm{~N}$ hydrochloric acid using phenolphthalein as an indicator. Removal of precipitated barium carbonate during titration was unnecessary. The determi= nation required about $10 \mathrm{~min}$ per sample with a recovery of more than $99 \%$ and a coefficient of varia $=$ tion within $0.5 \%$.

The proposed method was applied to the determination of sodium carbonate in various commercial granulate detergents. The results were compared with those from an autoanalyzer method. Good agreement was obtained with both methods, thus concluding the content of sodium carbonate in a granulated detergent can be determined more conveniently by the proposed method.
\end{abstract}

\section{1 緒 言}

JIS に記載される炭酸塩の純度分析は, 逆滴定による 中和滴定法 ${ }^{11}$ が主として利用されており, 一部カルシウ ム塩等は酸に溶解後, キレート滴定法 ${ }^{2}$ により定量され ている。しかし，広く利用される種々の炭酸塩が, 他の 成分と共存する時, 直接中和滴定やキレート滴定により 測定できることは, 極必て少ない。通常, 共存成分の影 響を除くため, 酸を加え発生する $\mathrm{CO}_{2}$ を種々の手段で 検出し定量している。

$\mathrm{CO}_{2}$ 定量法には, 直接検出する方法として重量減少を 測定するシュレッター法 ${ }^{3)}$, ガスクロマトグラフィーに よる方法 ${ }^{32}$ (5) 及び赤外線吸収法 ${ }^{6}$ 等がある。また, 間接 的な検出法として水酸化バリウム溶液に吸収させ, 過剩

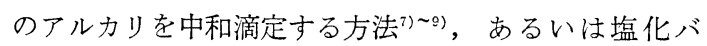
リウム溶液に吸収させ, バリウムイオンをキレート滴定
する方法 ${ }^{10)}{ }^{11}$ 及び水に吸収させ溶液電導度を測定する

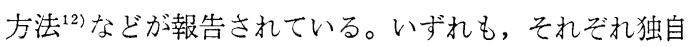
の特徴を有しているが, 著者らは特別な装置を必要とせ ず，日常手軽に扱える中和滴定法について検討した。

酸分解一中和滴定法は, 試料酸を加え発生する $\mathrm{CO}_{2}$ を炭酸バリウムとして固定化し, 過㮃の水酸化バリウム を酸滴定することで, 炭酸塩を定量するものである。こ のように単純な原理であるにもかかわらず，これまでボ イラー水や海水中の全炭酸の定量 ${ }^{7,8)}$ や土塨中の炭酸力 ルシウムの測定 ${ }^{9}$ に実施例がみられるだけで，その利用 度は極めて少ない。この理由は, 簡便で迅速な $\mathrm{CO}_{2}$ の 完全な固定化法が知られていないためであった。

著者らは, 気密性に優れた小型の空気ポンプを利用す ることで, 従来よりも高濃度の $\mathrm{CO}_{2}$ を迅速に固定化で きる方法を見いだした。その結果, 滴定法の正確さ及び 精度に優れるという利点とともに, 共存成分の影響をほ 
とんど受けることのない簡便で, 迅速な分析法を開発で きたので報告する。

\section{2 実験}

\section{$2 \cdot 1$ 試薬}

$2 \cdot 1 \cdot 1 \quad 1 \mathrm{~N}$ 塩酸標準溶液 : 濃塩酸 (試薬特級) $85 \mathrm{ml}$ を水で $1 l$ 亿希釈し，炭酸ナトリウム（一次標準試薬） によりファクターを算出した。

$2 \cdot 1 \cdot 2 \quad 0.2 \mathrm{~N}$ 水酸化バリウム溶液: 水酸化バリウム 8 水塩 (試薬特級) $31.5 \mathrm{~g}$ に水 $1 l$ を加え, 約 $70^{\circ} \mathrm{C}$ の 水浴中で加温し溶解する。放冷後沪過し, この溶液はソ 一ダ石灰管を付けた試薬瓶に保存した。

$2 \cdot 1 \cdot 3$ 希塩酸 $: 2 \mathrm{~N}$ 塩酸溶液を使用した。

$2 \cdot 1 \cdot 4$ 炭酸ナトリウム: 炭酸ナトリウム（試薬特級） を $550 \pm 50^{\circ} \mathrm{C}$ で加熱乾燥した後使用した。

$2 \cdot 1.5$ 炭酸水素ナトリウム: 炭酸水素ナトリウム(試 薬特級) を硫酸デシケーター中に二昼夜放置し乾燥した のち使用した。

$2 \cdot 1 \cdot 6$ 炭酸カルシウム: 炭酸カルシウム（試薬特級） を $110^{\circ} \mathrm{C} て ゙ 2 \mathrm{~h}$ 乾燥した後使用した。

$2 \cdot 1 \cdot 7 n$-オクチルアルコール（試薬一級）

水はすべてイオン交換水を使用した。

\section{2 炭酸塩定量操作}

炭酸塩定量装置を Fig.-1 に示した。

試料は炭酸ナトリウムとして $0.1 \sim 0.8 \mathrm{~g}$ となるよう $\mathrm{CO}_{2}$ 発生管 (1) (250 ml 容量のガス洗浄瓶) に精ひょ5 寸る。水約 $100 \mathrm{ml}$ で溶解（あるいは分散）させる。循 環する際, 発泡するような試料には $n$-オクチルアルコ 一ルを消泡剤として十数滴加え，その影響を除く。別に 乾燥した $\mathrm{CO}_{2}$ 吸収管 (2) (250 ml 容量のガス洗浄瓶) に $0.2 \mathrm{~N}$ 水酸化バリウム溶液 $100 \mathrm{ml}$ を正確にとり, $n-$

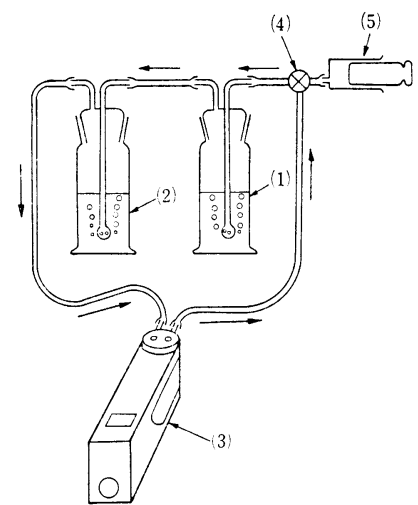

(1) $\mathrm{CO}_{2}$ occurrence bottle $(250 \mathrm{ml})$

(2) $\mathrm{CO}_{2}$ absorbing bottle $(250 \mathrm{ml})$

(3) Circulating air pump

(4) 3 -way cock

(5) Syringe $(50 \mathrm{ml})$

Fig.-1 Apparatus for determination of carbonate.
オクチルアルコール十数滴を加える。Fig. -1 のように 装置を取り付けすり合わせ部分をよく確認し, 空気ポン プ (柴田化学製ミニポンプ MP-2 型, 循環流量約 $2 l$ min）により装置内の空気を循環させながら, $\mathrm{CO}_{2}$ 発生 管に三方コック (4) を通じ注射器 (5)（テルモシリンジ $50 \mathrm{ml}$ 容量)により希塩酸 $20 \mathrm{ml}$ を加える。三方コッ クを切り換え, 更に $5 \mathrm{~min}$ 循環を続ける。

$\mathrm{CO}_{2}$ 吸收管を取りはずし, 内壁を水で洗浄した後沈 殿を分離することなく, 過剩の水酸化バリウムをフェノ ールフタレインを指示薬とし $1 \mathrm{~N}$ 塩酸標準液で滴定す る。別に, 空試験として $0.2 \mathrm{~N}$ 水酸化バリウム溶液 $100 \mathrm{ml}$ を滴定し, こ机らの滴定值から試料中の炭酸塩 を算出する。

\section{3 結果と考察}

炭酸塩の分解に使用する酸には塩酸, 硫酸, 硝酸及び 過塩素酸などが挙げられるが, 硫酸は炭酸カルシウム等 の測定に不溶性硫酸塩を形成し, また, 硝酸注試料に還 元性物質を含むとき酸化性窒素を発生するなど，いずれ も不適当である。ここでは過塩素酸に比べ扱い慣れてい る塩酸を選んだ。

\section{$3 \cdot 1$ 二酸化炭素の固定化に及ぼす循環時間の影響}

本法で炭酸塩の分解使用寸る塩酸は, 揮発性の酸と して良く知られている。そこで Fig.-1 の装置で $\mathrm{CO}_{2}$ 発生管に水 $100 \mathrm{ml}$ をとり, 希塩酸を加えてから空気ポ ンプで系内を $20 \mathrm{~min}$ 循環させた。しかし, 吸収液であ る水酸化バリウム溶液の塩酸滴定值は, 循環前及び循環 後でまったく変わらなかった。これは $\mathrm{CO}_{2}$ 発生管中の 塩酸濃度が薄い $(0.33 \mathrm{~N})$ ために室温で空気を通気する 程度では塩化水素の水への溶解性がをさり, 影響されな いものと考えられる。

次に発生した $\mathrm{CO}_{2}$ を炭酸バリウムとして固定化する のに必要な循環時間の影響を調べた。空気ポンプの循環 流量は約 $2 l / \mathrm{min}$ と大きいこともあり, 循環時間約 3 min でほぼ完全に固定化できることがわかった。この 結果から循環時間は $5 \mathrm{~min}$ とした。

\section{2 大気中の $\mathrm{CO}_{2}$ の影響}

水酸化バリウム溶液を滴定する際の大気中の $\mathrm{CO}_{2}$ (0.03\%) の影響について調べた。 $\mathrm{CO}_{2}$ 吸収管に $0.2 \mathrm{~N}$ 水酸化バリウム溶液 $100 \mathrm{ml}$ をとり, 大気中に放置した ときの滴定值の変化を調べた。その結果, 約 $30 \mathrm{~min}$ 放 置しても測定に影響しないことがわかり, 通常の滴定と 同様に，大気中での操作が可能であることを確認した。

\section{3 炭酸塩及び炭酸水素塩の定量及び定量精度}

炭酸ナトリウム, 炭酸カルシウム及び炭酸水素ナトリ ウムのそれぞれ乾燥品を, $2 \cdot 2$ に従い定量した結果を

Table-1 に示した。

正確さ及び精度共汇優れており, これらの結果は, 純 
Table-1 Reproducibility of the proposed method on carbonates and hydrogencarbonate determinations.

\begin{tabular}{l|r|r|r|r|r}
\hline Sample & $n$ & Range (\%) & Mean (\%) & S.D. & C.V.(\%) \\
\hline $\mathrm{Na}_{2} \mathrm{CO}_{3}$ & 5 & $99.6 \sim 100.5$ & 100.1 & 0.34 & 0.34 \\
$\mathrm{CaCO}_{3}$ & 5 & $98.9 \sim 99.8$ & 99.4 & 0.32 & 0.32 \\
$\mathrm{NaHCO}_{3}$ & 5 & $99.6 \sim 100.5$ & 100.0 & 0.47 & 0.47 \\
\hline
\end{tabular}

度分析法としての利用も可能なことを示している。

\section{4 市販洗浄剂中の炭酸塩の定量}

通常, 粉末衣料用洗郕には炭酸ナトリウムが 5 20\% 程度含まれている。その測定にはシュレッター法 ${ }^{3)}$ ， キ レート滴定法 ${ }^{10), 11)}$ ，ガスクロマトグラフィーによる方

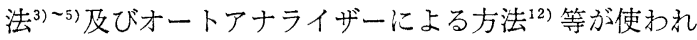
ている。しかし，これらの方法には，それぞれ測定精度 が悪い，操作が繁雑で長時間を要する，試料採取量が少 なく洗剂成分のばらつきを反映しやすい，及び自動分析 は可能であるが高価な装置を必要とする，などの欠点が ある。そこで，本法による粉末衣料用洗剤中の炭酸ナト リウムの定量を行った。発生管には適量のオクチルアル

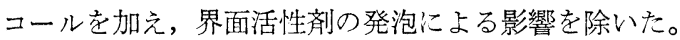

標準洗剤に炭酸ナトリウムを添加し，回収した結果を

Table-2 に示した。さらに同標準洗剤に 10\%炭酸ナト リウムを配合し，繰り返し分析した結果を Table-3 に 示した。

本法注試料採取量が約 $5 \mathrm{~g}(3 \sim 7 \mathrm{~g})$ と従来の方法に 比べ多くなっており，粉末洗剤成分の活らつきによる影 響を受けにくい利点があり，更に希勫の操作を必要とし ないなど，本法の簡便性と共に分析值の正確さを確認す ることができた。試料 1 件の分析所要時間は約 $10 \mathrm{~min}$ である。

本法による市販の粉末衣料用洗剂の分析結果を，オー トアナライザー法 ${ }^{12)}$ と共に Table-4 に示した。ただ し，試料自身のばらつきによる誤差をなくすため，一定 濃度の試料溶液を調製し，その一部を本法とオートアナ

Table-2 Recovery of sodium carbonate added in a standard detergent.

\begin{tabular}{c|c|c}
\hline Present $(\%)$ & Found $(\%)^{*}$ & Recovery $(\%)$ \\
\hline 0 & 0.01 & - \\
4.6 & 4.6 & 100.0 \\
9.3 & 9.3 & 100.0 \\
16.9 & 16.7 & 98.8 \\
23.0 & 22.9 & 99.6 \\
\hline
\end{tabular}

* Mean value of 3 determinations

Standard detergent used :

Scdium dodecylbenzene sulfonate : $24 \mathrm{wt} \%$

Soap : $1 \mathrm{wt} \%$

Zeolite : $19 \mathrm{wt} \%$

Sodium sulfate : $42 \mathrm{wt} \%$

Sodium silicate : $14 \mathrm{wt} \%$
Table-3 Repeatability on the determination of sodjum carbonate in a standard detergent.

\begin{tabular}{c|c|c|c|c|c}
\hline Present (\%) & $n$ & Mean (\%) & Range (\%) & S.D. & C.V. (\%) \\
\hline 10.1 & 5 & 10.0 & $10.0 \sim 10.1$ & 0.055 & 0.55 \\
\hline
\end{tabular}

Table-4 Determination of sodium carbonate in commercial detergents by proposed and Autoanalyzer methods.

\begin{tabular}{c|c|c}
\hline Sample & Proposed method* & Autoanalyzer method* \\
\cline { 2 - 3 } A & $5.8 \%$ & $5.9 \%$ \\
B & 19.5 & 19.1 \\
C & 24.5 & 24.1 \\
\hline
\end{tabular}

* Mean value of 4 determinations.

ライザー法とに供給し分析した。

両者は良い対応を示しており，いずれも粉末衣料用洗 剂への適用が充分可能であると考えられる。

また, 水不溶性の炭酸カルシウムは, 歯磨剤やクレン ザー等の研磨成分としてしばしば利用される。そこで， 標準歯磨剤を調製し，本法により炭酸カルシウムを定量 したところ，47.0\%の配合に対し，99.4\%の回収結果を 得ることができた。

その外，洗浄剤以外にも炭酸塩の利用例は多岐にわた っており，本法はこれらの対象に対しきわめて実用性の 高い定量方法であると考えられる。

\section{4 総括}

酸分解一中和滴定法による迅速で簡便な粒状洗剤中の 炭酸塩定量法を開発した。すなわち, 試料に塩酸を加え 炭酸塩の分解により発生する $\mathrm{CO}_{2}$ を水酸化バリウム溶 液に導き，炭酸バリウムとして固定化する。その際， $\mathrm{CO}_{2}$ 発生管は $\mathrm{CO}_{2}$ 吸収管及び小型の循環空気ポンプに 接続し,密閉循環系とすることで発生する $\mathrm{CO}_{2}$ は $5 \mathrm{~min}$ の循環で完全に吸収液に固定化できた。ついで, 沈殿の 共存するまま塩酸標準液で滴定することにより炭酸塩を 定量した。

本法によれば，分析所要時間注約 $10 \mathrm{~min}$ であり，炭 酸ナトリウム (試薬) の定量值は $100.1 \%$, 変動係数 $0.34 \%$ と信頼性の高い結果を得た。また，粉末衣䊀用洗 剤のように複雑な組成から成る試料に関しても，10％添 加配合した炭酸ナトリウムは平均回収率 $99.0 \%$, 変動 係数 $0.55 \%$ であり，共存成分の影響をまったく受ける ことなく定量可能であった。その他, 炭酸カルシウムの ような不溶性炭酸塩についても適用でき, 良好な結果を 得ることができた。また, 本法は吸収液及びその滴定液 の濃度を変えることで, 炭酸塩の定量範囲を比較的自由 に変えることができる。特に水中に溶存する全炭酸の測 定も，両溶液濃度を $1 / 10$ に希釈することで測定可能 ${ }^{13)}$ となるなど，応用範囲の広い炭酸塩分析法である。 
(昭和 59 年 2 月 24 日受理)

\section{文献}

1）JIS K 8625 “炭酸ナトリウム (無水) (試薬)” (1978) な ど

2) JIS K 8617 “炭酸カルシウム (試薬)” (1978) など

3） JIS K 3362 “合成洗凧試験方法” (1978)

4) F.G. Carpenter, Anal. Chem., 34, 66 (1978)

5) 藤田 学, 浅見晃生, 井上恵雄, 林 信太, 油化学, 23, 188 (1974)
6) H. Pobiner, Anal. Chem., 34, 878 (1962)

7）小山忠四郎, 菅原 健, 日化, 65, 703 (1944)

8) D. Parkhouse, Chem. Ind. (London), 1953, 1197

9) C.J. Schollenberger, C.W. Whittaker, Soil. Soci., 85, 10 (1958)

10) 永井敏雄, 二本木恒夫, 油化学, 20, 816 (1971)

11）川畑正夫, 望月平一, 梶山緑郎, 渡辺正雄, 石井雅夫, 佐々木浩三, 分化, 11, 192 (1962)

12) 川瀬次郎, 山中 実, 油化学, 27, 602 (1978)

13）未発表 